[Letter]

\title{
Biomarker Discrimination of Pyrolysis Oil Derived from Activated Sludge and Heavy Oil from Crude Oil
}

\author{
Masato TAKI ${ }^{\dagger 1), \dagger 2)}$, Shamsul $\operatorname{IZHAR}^{\dagger 1)}$, and Masatoshi $\mathrm{NAGAI}^{\dagger 1) *}$ \\ ${ }^{\dagger 1)}$ Graduate School of Bio-applications and Systems Engineering, Tokyo University of Agriculture and \\ Technology, 2-24 Nakamachi, Koganei, Tokyo 184-8588, JAPAN \\ ${ }^{\dagger 2}$ Coast Guard Research Center, Japan Coast Guard, 1156 Izumi, Tachikawa, Tokyo 190-0015, JAPAN
}

(Received December 2, 2010)

Analysis of bio-oil derived from activated sludge using biomarkers was performed by spectroscopic methods. The method successfully determined the distinction between the oil derived from activated sewage sludge (bio-oil) and crude oil (heavy fuel oil).

Keywords Biomarker, Bio-oil, Sterane, Activated sludge, Heavy oil

Fast pyrolysis bio-oil is attracting interest because of its high energy density, ease of transportability and convenience of use. The bio-oil is composed of a very complex mixture of oxygenated hydrocarbons and is often referred to as bio-oil ${ }^{1)}$. However, activated sludge derived bio-oil has been reported to contain high amount of polycyclic aromatic hydrocarbon, nitrogen and sulfur hydrocarbons. Due to this, most investigators are interested in the study of nitrogen removal in order for it to be used as fuel for direct combustion. Abundant literature is available focusing on optimizing the bio-oil yield, however little attention was provided to the quality of the bio-oil produced. With the increasing interest in usage and upgrading of bio-oil, it is imperative to understand the effect of feedstock chemistry and process parameters and accurately predict the yields of compositions present in bio-oils. In this study, we report the distinction between the fast pyrolysis bio-oil from sewage sludge and heavy oil from imported Arabian heavy crude (denoted as heavy oil from this point onwards). In a previous paper ${ }^{2}$, the discriminatory analysis of 41 crude oils using biomarkers revealed the difference between many crudes by territories.

In the present work, heavy oil was obtained from JX Nippon Oil \& Energy Corp. The activated sludge was from an industrial and municipal wastewater treatment facility (Ako Waste Sewage Plant Center). The sludge was pyrolyzed at $500^{\circ} \mathrm{C}$ in a stream of fluidized gas $\left(\mathrm{H}_{2} \mathrm{O}, \mathrm{N}_{2}\right.$ and air; $\left.\mathrm{H}_{2} \mathrm{O} / \mathrm{feed}=1.2-1.8\right)$ in a internally circulating fluidized bed gasifier by feeding continuously at a rate of $60 \mathrm{~g} / \mathrm{h}$, at gas resident time of 1 s. Liquid products hydrocarbon (bio-oil) yield from activated sludge was $50 \%$. Elemental analysis showed the bio-oil consists of $\mathrm{C}=75.0, \mathrm{H}=10.1, \mathrm{O}=13.4$, $\mathrm{N}=5.5 \%$. In this study, gel permeation chromatography

“バイオマーカー分析による活性污泥由来バイオオイ ルと重油との識別分析” 滝優人 ${ }^{\dagger 1)} \uparrow{ }^{\dagger}$, , Shamsul $\mathrm{IZHAR}^{\dagger 11}$, 永井正敏 ${ }^{\dagger 11}$. ${ }^{\dagger 1}$ 東京農工大学大学院工学 研究院, 184-8588 東京都小金井市中町 2-24. ${ }^{\dagger 2}$ 海上. 保安試験研究センター, 190-0015 東京都立川市泉町 1156. *連絡先 mnagai@cc.tuat.ac.jp

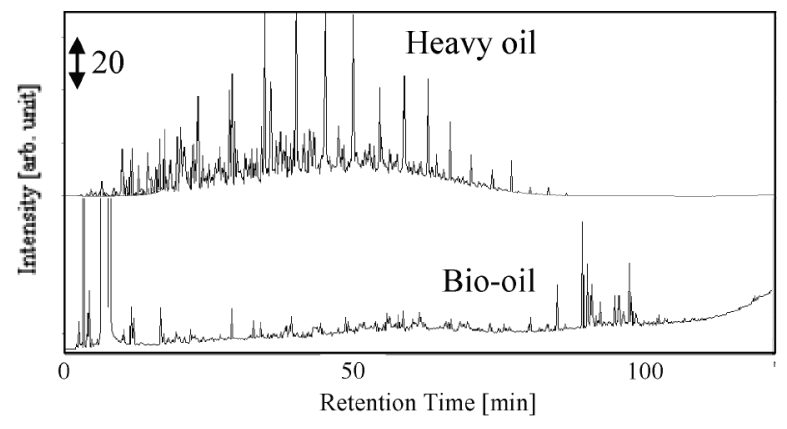

Fig. 1 GC Chromatograms of Heavy Oil and Bio-oil Analyzed Using a GC-MS

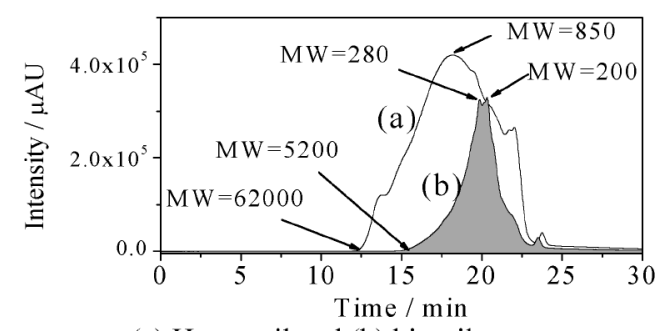

(a) Heavy oil and (b) bio-oil.

Fig. 2 Molecular Weight Distribution by Gel Permeation Chromatography

was performed using uv-visible dual/multiwave length detector (JSC), detector wavelength $254 \mathrm{~nm}$, column (Shodex GPC KF-802) $40^{\circ} \mathrm{C}$ and THF mobile phase (1 $\mathrm{mL} / \mathrm{min})$. IR analysis was performed using an FT-IR spectrometer (FT/IR-410) equipped with a ceramics laser and DLATGS detector. IR spectra from 650-4000 $\mathrm{cm}^{-1}$ were collected using a liquid thin film and $\mathrm{KBr}$ cell method. The detail oil components were identified using a GC-MS (Agilent 7890) equipped with a DB5 capillary column (J\&W). The injection and GC-MS transfer line temperatures were $320^{\circ} \mathrm{C}$. Column oven temperature was programmed from $80^{\circ} \mathrm{C}$ to $300^{\circ} \mathrm{C}$ at a rate of $6^{\circ} \mathrm{C} / \mathrm{min}$ and maintained $20 \mathrm{~min}$. The carrier gas was helium gas $(1 \mathrm{~mL} / \mathrm{min})$ with split ratio of 1:50. Mass spectrometer ion source was operated in EI+ mode $(70 \mathrm{eV}, 300 \mu \mathrm{A})$. The samples were identified by comparison of their spectra with the library spectra. 
Figure 1 illustrates the GC chromatograms of the heavy oil and the bio-oil analyzed with GC-MS. Heavy oil showed many peaks appearing constantly every 5 min, which were attributed to paraffins consisting of $\mathrm{C}_{7} \mathrm{H}_{16}$ to $\mathrm{C}_{29} \mathrm{H}_{60}$. On the other hand, the bio-oil exhibited several large peaks at above $80 \mathrm{~min}$ due to the presence of high boiling point components. The peaks of the bio-oil were not observed in the heavy oil and vice-versa. These GC results showed a major distinction between the heavy oil and bio-oil. The results from gel permeation chromatography of heavy oil and the bio-oil dissolved in $0.1 \%(\mathrm{~W} / \mathrm{V}) \mathrm{THF}$ solution are shown in Fig. 2. Using a standard curve constructed with the molecular weight of polystyrene, the maximum molecular weight $(M W)$ of the bio-oil was about 5200 with the highest distribution observed between 200 and 280 . On the other hand, heavy oil illustrated a tenfold higher maximum $M W$ and fivefold larger distribution $M W$ (peak area) than the bio-oil. This difference can be attributed to the fact that sewage sludge contains algae, higher plants, carcasses of bacteria, lipid and other constituents of microorganisms. On the contrary, the crude oils mainly originated from bacteria residues in rocks and mud stone rocks, and were generated by decomposition together with heat and pressure after very long period ${ }^{3)}$.

The results from the IR measurement (Fig. 3) of the heavy oil showed a sharp expansion and vibration absorption of methyl and methylene derivatives around 2960 and $2850 \mathrm{~cm}^{-1}$, respectively. On the other hand, the bio-oil displayed the same sharp peak 2960 and $2850 \mathrm{~cm}^{-1}$ together with large broad peaks at $3200 \mathrm{~cm}^{-1}$. The broad IR absorption band at $3100-3600 \mathrm{~cm}^{-1}$ is indicative of a large presence of nitrogen and water in the $\mathrm{N}-\mathrm{H}$ and $\mathrm{OH}$ group, respectively.

The components present in the bio-oil were studied in detail by GC-MS. Selected-ion-monitoring is used in the present study for the biomarker analysis. The ion of $m / z=191$ and 217 is often diagnostic of the structure of hopane and sterane compounds, respectively ${ }^{4}$, in a parallel study with the retention times of the gas chromatogram. Figure $\mathbf{4}$ shows the mass chromatograms for sterane $(\mathrm{m} / \mathrm{z}=217)$, sterol $(271)$ and hopane (191), and their relation in terms of retention time on the bio-oil. The total ionic chromatogram showed very similar peaks to that obtained for $m / z=217$ for a major fragment of sterane which is derived from sterol pyrolysis. The $m / z=271$

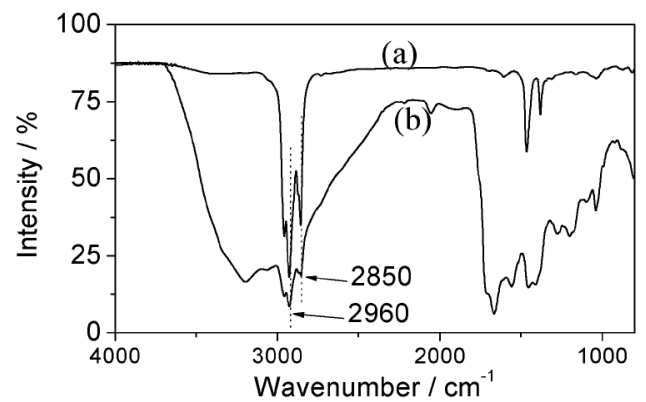

Fig. 3 FT-IR Measurement of (a) Heavy oil and (b) Bio-oil

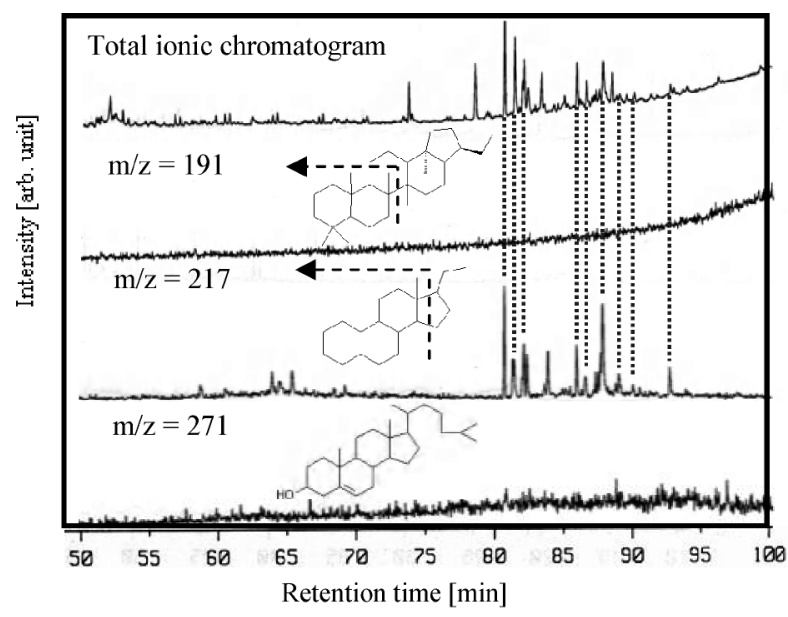

Fig. 4 Selected Ion Monitoring (SIM) of Sterane $(\mathrm{m} / \mathrm{z}=$ 217), Sterol (271) and Hopane (191) during GC-MS Analysis of Bio-oil Dissolved in Acetone

for the fragment of sterols was not found in bio-oil. Although the bio-oils derived from activated sludge contained microorganisms and sterols, sterols could have decomposed to steranes $(m / z=217)$ during fast pyrolysis process of activated sludge to bio-oil. On the other hand, heavy oil from Arabian crude includes little sterane due to degradation of sterols during long period, but contained hopane homologs for the ion of $\mathrm{m} / \mathrm{z}=$ 191 as a major fragment. Moldowan et al. ${ }^{5}$ reported high quantity of hopanes but minor $\mathrm{C}_{30}$ steranes in several crude. It is worth noting that the current analysis of the bio-oil did not show any assignable peaks related to $m / z=191$ for hopanes. Thus, bio-oil derived from sewage sludge did not contain any hopanes, but contained high amount of sterane core containing compound. Furthermore, GC-MS measurement also indicates the presence of sterane core compounds with carbon number $\mathrm{C}_{27}$ to $\mathrm{C}_{29}$ in the bio-oil. Therefore, in this work, it is proven that bio-oils can be discriminated from heavy oil by the compositions of sterane and hopane based on the biomarker analysis.

\section{Acknowledgments}

The authors thank Prof. N. Yoshida (Wakayama Univ.), Prof. Y. Yamamoto (Osaka Univ.) and Prof. T. Morioka (Kansai Univ.) for their support in this work.

\section{References}

1) Bridgwater, A. V., Appl. Catal. A: Gneneral., 116, 5 (1994).

2) Taki, M., Asahara, T., Mandai, Y., Uno, T., Nagai, M., Energy \& Fuels, 23, 5003 (2009).

3) Damsté, J. S. S., Kuypers, M. M. M., Pancost, R. D., Schouten, S., Org. Geochem., 39, 1703 (2008).

4) Aznar, M., Anselmo, M. S., Manya, J.J., Murillo, M. B., Energy \& Fuels, 23, 3236 (2009).

5) Moldowan, J. M., Seifert, W.K., Gallegos, E. J., $A A P G$ Bull., 69, 1255 (1985). 